\title{
Robert E. Meditz The Dialectic of the Holy: Paul Tillich's Idea of Judaism within the History of Religion
} (Berlin and Boston: De Gruyter, 2016), hardcover, pp. xiv + 208

\author{
GEORGE PATTISON \\ george.pattison@glasgow.ac.uk \\ University of Glasgow, Glasgow G12 8QQ, United Kingdom
}

A decisive moment in Paul Tillich's life and in the history of his relation to Judaism was Hitler's accession to power in 1933. As Meditz notes, Tillich was one of over 1600 academics suspended in April 1933 "for being Jews and / or critics of the regime" (p. 1). At the time, Tillich held a professorial post in the philosophy faculty of the University of Frankfurt and was thus close to the epicentre of radical leftist thinking ("the Frankfurt School") and associated with several leading Jewish philosophers (such as Theodor Adorno). Tillich's most recent book, The Socialist Decision (1933), was for long believed to have been not only banned but ritually burned in the Frankfurt book-burnings of May 1933, though Meditz seems to favor the revisionist view that this was not in fact the case (p. 75). But though he was regarded with suspicion by the new regime, Tillich was later that year offered the chair of theology in Berlin if he was willing to retract The Socialist Decision. According to Hannah Tillich, his response was to ask two questions, one of which was "What about the Jews?" Clearly the government's response did not satisfy him, and shortly afterwards he left Germany to go into what proved to be permanent exile in the United States of America.

This new study, based on the author's Ph.D. thesis, sets these dramatic events in the context of Tillich's lifelong engagement with "the Jewish question," from his postgraduate work on Schelling through his final public lecture on the relationship between the history of religion and systematic theology. He was deeply rooted in the thought-world of German Idealism and therefore, according to some commentators, took his initial orientation from a philosophy that was inherently anti-Judaic. However, Meditz shows that Tillich reached a position that was no longer simplistically supersessionist. On the contrary, by 1933 he had reached the view "that Judaism was vitally important for Christian theology" (p. 3) and, as he argued in a 1938 speech in New York's Madison Square Garden, "the struggle for the eradication of Judaism is ... a struggle to eradicate Christianity" (p. 4). 
In his early Schelling dissertations (1910 and 1912) Tillich seems to have endorsed German Idealism's view of Christianity as resolving the contradictions of Judaism and paganism. The main impetus to a new approach seems, in the first instance, to have been his existential experience of the First World War and his consequent embrace of religious socialism (pp. 64-66). This also included his involvement with a discussion group known as the "Kairos circle," which included both Christian and Jewish members. From here it was a relatively short step to his association with the Frankfurt School and the events of 1933.

His early, conventional picture of Judaism as being defined by external legalism shifted to a view emphasizing the primacy of prophetism in Judaism. But prophetism, as Tillich understands it, is also integrally related to Christianity (not least to the "Protestant principle"). A continuing relation to Judaism becomes necessary for Christianity to remain true to its own identity (although Tillich does, briefly, suggest that some elements in Judaism also have an affinity with capitalism [p. 71]). But Judaism too needs to remember its own prophetism, if $\mathrm{Zi}$ onism is not to lead to a new kind of nationalistic religious conformism (see pp. 73 and 92-93).

As Meditz shows, The Socialist Decision sees Jewish prophetism as a resource against the "blood and soil" ideology of Nazism but also, more positively, as posing an unremitting demand for eschatological justice, summed up in the phrase "justice is the true power of being" (p. 77). The stage is thus set for a conflict between, on the one hand, the kind of political romanticism that seeks value and grounding in the powers of origin and, on the other, the kind of prophetic religion that seeks a justice to come. This is also a struggle between the cyclical time of nature religions and the kind of time that "moves towards something that did not exist but will exist and, once it is attained, will not be lost again" (p. 90).

It now becomes clear why The Socialist Decision was irreconcilable with Nazism. As such it also indicates at an early stage what will become Tillich's mature view of Judaism. This is further deepened in an invited series of lectures on the Judenfrage ("the Jewish Question") given in 1952 at the Deutsche Hochschule für Politik, which explores many historical and contemporary aspects of the question over and above the importance of Jewish prophetism, including the question of war guilt. Overall, the lectures emphasize continuity and convergence between Judaism and Christianity to a degree that is very unusual in Christian theology, even post-1945. The idea that Judaism provides an "indispensable basis" for Christianity continues to be emphasized in Tillich's Systematic Theology, although this is clearly in tension with Tillich's defining view of the coming of Jesus as the Christ as the "center of history."

Tillich clearly emerges very creditably from this study, although Meditz notes the objection that his whole view of Judaism is "utterly useless" (p. 177) because he forces Judaism into a typology of his own contriving and does not let it speak for itself. However, in my view one might make a similar criticism of just about any aspect of Tillich's thought, which is always based on ideal types rather than empirical examples. Of course, it may be that such idealism is altogether "utterly useless," but at least the evidence of Tillich's life shows that it can inspire 
positions that are honorable and maintained with significant courage in the face of opposition.

There is little else out there on the theme of Tillich and Judaism. Meditz's work, while bearing traces of its origins in a Ph.D. thesis, does the job it sets out to do and, as such, is a welcome addition to Tillich commentary. 